\title{
Induction, characterization, and NMR-based metabolic profiling of adventitious root cultures from leaf explants of Gynura procumbens
}

\author{
Mohd Zuwairi Saiman • Natali Rianika Mustafa • \\ Anna Elisabeth Schulte • Robert Verpoorte • \\ Young Hae Choi
}

Received: 7 September 2011/ Accepted: 27 December 2011/Published online: 7 January 2012

(C) The Author(s) 2012. This article is published with open access at Springerlink.com

\begin{abstract}
Gynura procumbens is a medicinal plant used in South East Asia to treat various ailments such as rash, hemorrhoids, inflammation, and diabetes. In order to develop a large-scale culture system for G. procumbens biomass containing bioactive compounds, adventitious root cultures were initiated from leaf explants. Murashige and Skoog (MS) media containing different compositions of indole-3-butyric acid (IBA), 1-naphthalene-acetic acid (NAA), and combinations of both plant growth regulators (PGRs) were evaluated for root induction. A combination of $3 \mathrm{mg} / \mathrm{l} \mathrm{NAA}+1 \mathrm{mg} / \mathrm{l}$ IBA gave the highest root induction $(48 \%)$ as compared to other PGRs treatments after 9 weeks of incubation period. Subsequently, the adventitious roots were established in liquid culture containing MS medium and the combination of $3 \mathrm{mg} / \mathrm{l}$ $\mathrm{NAA}+1 \mathrm{mg} / \mathrm{l}$ IBA. A study on the medium strength, sucrose concentration, $\mathrm{pH}$, and light versus dark was conducted to optimize the in vitro culture conditions. The results showed that differences in MS medium strength from half to double strength, and light or dark condition did not significantly affect the biomass production, while the
\end{abstract}

M. Z. Saiman · N. R. Mustafa $(\bowtie) \cdot$ R. Verpoorte · Y. H. Choi Natural Products Laboratory, Institute of Biology, Leiden University, 2300 RA Leiden, The Netherlands

e-mail: mustafa@chem.leidenuniv.nl

M. Z. Saiman

Institute of Biological Sciences, Faculty of Science, University of Malaya, 50603 Kuala Lumpur, Malaysia

N. R. Mustafa $\cdot$ A. E. Schulte

ExPlant Technologies B.V., Einsteinweg 55, 2333 CC Leiden,

The Netherlands initial medium $\mathrm{pH}$ of 5.5 and $2 \% \mathrm{w} / \mathrm{v}$ sucrose concentration were most suitable for the root culture growth. Nuclear magnetic resonance (NMR) spectroscopy was performed to characterize the metabolite content in the root cultures of G. procumbens. Among the elucidated metabolites were some phenylpropanoids identified as caffeic acid, chlorogenic acid, and 3,5-di-O-caffeoylquinic acid which might be the bioactive compounds associated to the folk use of this plant.

Keywords Root induction - Organogenesis · Tissue culture $\cdot$ Plant growth regulator $\cdot$ Auxin . Phenylpropanoid
Abbreviations
DW Dry weight
FW Fresh weight
IBA Indole-3-butyric acid
MS Murashige and Skoog (1962) medium
NAA 1-Naphthalene-acetic acid
NMR Nuclear magnetic resonance
PGR Plant growth regulator

\section{Introduction}

Gynura procumbens (Lour.) Merr. is a medicinal plant belonging to the Asteraceae family. It has been extensively used as a traditional herbal medicine particularly in South East Asia. The plant is used for the treatment of many different ailments such as rash, kidney diseases, eruptive fever, hemorrhoids, and inflammation (Perry and Metzger 1980; Iskander et al. 2002). The leaf of G. procumbens is not toxic (Rosidah et al. 2009) and it has been used in folk medicine to control the blood sugar level of diabetic 
patients (Akowuah et al. 2002). In traditional Chinese medicine, the roots of Gynura species have been consumed for promoting microcirculation and relieving pain (Dai et al. 2007).

Due to the wide application of this plant in traditional medicine, a number of studies have been conducted to investigate different pharmacological activities. Zhang and Tan (2000) discovered that leaf extracts of G. procumbens significantly suppressed the level of elevated serum glucose, and reduced serum cholesterol and triglyceride levels in diabetic rats. Akowuah et al. (2002) and Hassan et al. (2010) showed significant hypoglycaemic effect of $G$. procumbens leaf extracts in streptozotocin-induced diabetic rats. In addition, Akowuah et al. (2002) isolated flavonol glycosides (e.g. kaempferol 3-O-glucoside and quercetin-3-O-rhamnosyl $(1 \rightarrow 6)$ glucoside $)$ as the major constituents in the $n$-butanol fraction of methanolic leaf extracts. Jiratchariyakul et al. (2000) reported that the plant extracts have anti-replicative action against herpes simplex virus and identified 3,5-di- $O$-caffeoylquinic acid and 4,5-di- $O$-caffeoylquinic acid as the active components. Moreover, the leaf or aerial parts of G. procumbens showed an anti-inflammatory (Iskander et al. 2002) and antihypertensive (Hoe et al. 2007) activity but the chemical properties as regard to the respective activities need to be further studied.

Despite the great medicinal value, adverse effects have also been associated with Gynura species due to the presence of pyrrolizidine alkaloids that cause hepatic veno-occlusive disease. There is little information available regarding pyrrolizidine alkaloids in G. procumbens as compared to other Gynura species, e.g. G. segetum has been reported to contain a number of pyrrolizidine alkaloids such as senecionine, seneciphylline, and seniciphyllinine (Qi et al. 2009). It was presumed that pyrrolizidine alkaloids in Gynura roots might be responsible for the hepatoxicity (Dai et al. 2007). Consequently, using this plant as an herbal product bears a risk of causing liver failure if the wrong species rich in pyrrolizidine alkaloids are used or when pyrrolizidine alkaloids content is increased due to cultivation or environmental conditions. Therefore, both correct botanical identification and quality control should be applied to ensure safe plant material.

Alternatives can be delivered by biotechnological means using in vitro cell or organ cultures which can be optimized for producing the desired metabolites and reducing the production of the toxic compounds. Plant cell suspension culture is the most popular approach since it gives a homogenous fast growing material, represents a simple technique and is easy to scale-up. However, the undifferentiated cells in a suspension culture may lack the biosynthetic machinery required for the generation of diverse secondary metabolites of interest, as different cell types may be involved to complete the pathway; therefore, a plant organ culture is a preferable system. Regarding the plant organ cultures, root culture is more favorable than the shoot culture because of rapid root multiplication and the ability of cultivation in large-scale bioreactors. The adventitious root cultures induced by plant growth regulators (PGRs) have been studied in various medicinal plants species such as Valeriana amurensis (Cui et al. 2011), Stevia rebaudiana (Reis et al. 2011), and Morinda citrifolia (Baque et al. 2010). In addition, adventitious root cultures of some medicinal plant species, e.g. Panax ginseng and Echinacea purpurea were successfully cultivated in large-scale bioreactors (e.g. Paek et al. 2005; Wu et al. 2007). The large-scale cultivation system of plant cell and tissue culture using bioreactor is promising for the production of biomass and phytochemicals. It offers several advantages such as automated mass propagation, controlled culture environment (e.g. oxygen, $\mathrm{pH}$, temperature, nutrient), consistency of the product, and reducing micropropagation cost (Paek et al. 2005).

Unlike other medicinal plant species, the in vitro culture has not been well studied with Gynura plants. Except for the establishment of a micropropagation system for clonal multiplication (Keng et al. 2009), there are no further reports on initiation of cell or organ cultures as a sustainable source of $G$. procumbens biomass. Therefore, additional reproducible production systems of $G$. procumbens plant material for use as such or as source of phytochemicals are of great interest.

Identification and characterization of chemical constituents in plant cell cultures are essential. The use of nuclear magnetic resonance (NMR) spectroscopy has recently received increasing interest in metabolomics and numerous plant-based studies. NMR was used to investigate metabolic changes in response to PGRs in tissue culture (Kim SW et al. 2011). Moreover, NMR has been applied to classify and characterize different species of (medicinal) plants, monitor the response to stress conditions in plants or plant cell cultures, discriminate between wild/transgenic plants or genotypes, define biomarkers in plant species or cell lines, and profile metabolites changes during long-term subculture period of cell culture (Kim HK et al. 2010, 2011).

In the present study, a leaf explants-derived adventitious root culture was developed as an alternative culture system for G. procumbens biomass containing bio-active compounds. In addition, the effects of medium strength, sucrose concentration, initial medium $\mathrm{pH}$, and light versus dark on root culture growth were evaluated. Moreover, the metabolite content in the root culture was characterized using an NMR-based profiling technique. 


\section{Materials and methods}

Plant material

The plant of $G$. procumbens (approximately 25-30 cm high) used in this study was bought from a herbal store in Delft, The Netherlands. The plant species was identified and confirmed by Dr M.M.J. van Balgooy from the National Herbarium of Netherlands, Leiden, The Netherlands.

\section{Explants preparation}

The upper leaves of the plant were taken and washed thoroughly under running tap water for $2 \mathrm{~h}$. Under aseptic conditions, leaves were surface-sterilized with $70 \% \mathrm{v} / \mathrm{v}$ ethanol for $30 \mathrm{~s}$, subsequently soaked in $10 \% \mathrm{v} / \mathrm{v}$ solution of commercial sodium hypochlorite (containing $5 \% \mathrm{w} / \mathrm{v}$ active ingredient) for $5 \mathrm{~min}$ and rinsed three times with sterile distilled water before drying on filter paper.

Root induction from leaf explants

The sterilized explants were cut to approximately $9 \mathrm{~mm}^{2}$ and placed on the media in petri dishes containing Murashige and Skoog (MS) medium supplemented with $30 \mathrm{~g} / \mathrm{l}$ sucrose, $2.5 \mathrm{~g} / \mathrm{l}$ gelrite, and different compositions of auxin(s) as follows:

1. $1 \mathrm{mg} / \mathrm{l}$ IBA

2. $3 \mathrm{mg} / \mathrm{l}$ IBA

3. $5 \mathrm{mg} / \mathrm{l}$ IBA

4. $1 \mathrm{mg} / \mathrm{l} \mathrm{NAA}$

5. $3 \mathrm{mg} / \mathrm{l} \mathrm{NAA}$

6. $5 \mathrm{mg} / \mathrm{l} \mathrm{NAA}$

7. $3 \mathrm{mg} / \mathrm{l} \mathrm{IBA}+1 \mathrm{mg} / \mathrm{l} \mathrm{NAA}$

8. $3 \mathrm{mg} / \mathrm{l} \mathrm{NAA}+1 \mathrm{mg} / \mathrm{l} \mathrm{IBA}$

The media were adjusted to $\mathrm{pH} 5.8$ with $1 \mathrm{M} \mathrm{NaOH}$ prior to autoclaving at $121^{\circ} \mathrm{C}$ for $20 \mathrm{~min}$. The cultures were incubated at $25^{\circ} \mathrm{C}$ in the dark. In each treatment, 10 explants were placed in a petri dish with 9 replicates. Frequency of root induction was determined as mean percentage of the explants producing roots after 5, 6, and 9 weeks of incubation. Analysis of variance (ANOVA) followed by Duncan's Multiple Range Test (DMRT) was performed on SPSS Statistics 17 (SPSS Inc., Chicago, IL, USA) to determine statistical differences $(P<0.05)$ between means of groups.

Initiation of root culture in liquid medium

The root cultures in liquid medium were initiated by inoculating two grams fresh weight $(\mathrm{FW})$ of the adventitious roots from MS solid medium supplemented with $30 \mathrm{~g} / \mathrm{l}$ sucrose and a combination of $3 \mathrm{mg} / \mathrm{l}$ $\mathrm{NAA}+1 \mathrm{mg} / \mathrm{l}$ IBA into the same medium without gelrite. The adventitious roots were cultured in $250 \mathrm{ml}$ Erlenmeyer flasks containing $100 \mathrm{ml}$ medium, fitted with a silicone foam stopper type T-32 (Shin-Etsu Polymer Co., Tokyo, Japan) and agitated at $100 \mathrm{rpm}$ on a gyrotary shaker (New Brunswick Scientific Inc., Enfield, CT, USA) in the dark and incubation temperature of $25^{\circ} \mathrm{C}$. The root cultures were maintained by routine subculturing at 4 weeks intervals. These root cultures were used as samples for further experiments.

Determination of growth curve

In order to determine the growth curve of G. procumbens root cultures, two grams FW of 3-week-old root cultures were inoculated into the same liquid medium and the same culture conditions as the one employed for routine subculturing. The root cultures were harvested by washing the tissues with Milli- $Q^{\mathrm{TM}}$ water and the water was removed by filtration under moderate vacuum pressure. The roots FW were determined after blotting the roots on tissue papers. Subsequently, the roots were dipped into liquid nitrogen and lyophilized in freeze drier (Edwards Ltd., Crawley, England). After 7 days, the tissues were weighed to determine the dry weight (DW). The growth curves were plotted according to FW and DW of roots biomass from two replicates flasks that were harvested weekly for up to 8 weeks.

\section{Optimization of culture conditions}

Two grams FW of the 3-week-old root cultures were used as inocula in $250 \mathrm{ml}$ Erlenmeyer flask containing $100 \mathrm{ml}$ of MS medium supplemented with a combination of $3 \mathrm{mg} / \mathrm{l}$ $\mathrm{NAA}+1 \mathrm{mg} / \mathrm{l}$ IBA. The root cultures were incubated at $24.8 \pm 2{ }^{\circ} \mathrm{C}$ and agitated on a gyrotary shaker (New Brunswick Scientific Inc., Enfield, CT, USA) at $100 \mathrm{rpm}$. The MS medium strengths $(1 / 2,1,3 / 2$, and 2), sucrose concentrations $(1,2,3,5,7$, and $10 \% \mathrm{w} / \mathrm{v})$, initial medium $\mathrm{pH}$ (5.0, 5.5, 5.75, 6.0, and 6.5), and light (placed under continuous fluorescent light at 1,500-2,000 lux) versus dark were studied to optimize tissue culture conditions. Except when mentioned otherwise, inocula were cultured on normal strength (1) MS liquid medium supplemented with $30 \mathrm{~g} / \mathrm{l}$ sucrose, initial medium $\mathrm{pH}$ of 5.8 prior to autoclaving, and incubated in the dark. Three biological replicates were assigned for each treatment in each study except that 5 replicates were used to study for the light versus dark conditions. The root cultures were harvested 4 weeks after inoculation, and biomass accumulation was 
evaluated by weighing FW and DW. The root FW was determined as described previously and the DW of the roots was acquired after 5 days freeze drying. Analysis of variance (ANOVA) followed by Duncan's Multiple Range Test (DMRT) was performed on SPSS Statistics 17 (SPSS Inc., Chicago, IL, USA) to determine statistical differences $(P<0.05)$ between means of groups.

\section{Metabolite analysis}

The 4-week-old adventitious roots of $G$. procumbens cultured in the maintenance liquid medium were subjected to metabolite analysis by one-dimensional and twodimensional ${ }^{1} \mathrm{H}-\mathrm{NMR}$. Fifty milligrams of freeze-dried adventitious roots were added with $1.2 \mathrm{ml}$ of methanol- $d_{4}$ and $0.3 \mathrm{ml}$ of potassium dihydrogen phosphate buffer in deuterium oxide ( $\mathrm{pH}$ 6). Subsequently, the samples were vortexed for $10 \mathrm{~s}$ and sonicated for $15 \mathrm{~min}$ at the frequency of $42 \mathrm{kHz}$ using an Ultrasonicator 5510E-MT (Branson, Danbury, CT, USA). After that, the extracts were centrifuged (Eppendorf type-5415C, Harmburg, Germany) at $16,000 \mathrm{~g}$ for $10 \mathrm{~min}$. An aliquot of $0.8 \mathrm{ml}$ of the supernatant was used for NMR measurement. The NMR spectra were recorded at $25^{\circ} \mathrm{C}$ on a $600 \mathrm{MHz}$ Bruker DMX 600 spectrometer (Bruker, Karlsruhe, Germany) operating at proton NMR frequency of $600.13 \mathrm{MHz}$. Methanol- $d_{4}$ was used as the internal lock. The ${ }^{1} \mathrm{H}-\mathrm{NMR}$ spectra consisted of 128 scans requiring $10 \mathrm{~min}$ and $26 \mathrm{~s}$ acquisition time with following parameters: $0.16 \mathrm{~Hz} /$ point, pulse width of $30^{\circ}(11.3 \mu \mathrm{s})$, and relaxation delay of $1.5 \mathrm{~s}$. A presaturation sequence was used to suppress the residual water signal with low power selective irradiation at the water frequency during the recycle delay. Free induction decay was Fourier transformed with a line broadening factor of $0.3 \mathrm{~Hz}$. The resulting spectra were manually phased, baseline corrected, and calibrated to trimethylsilyl propionic acid sodium salt (TMSP- $d_{4}$ ) at $0.0 \mathrm{ppm}$ by using XWIN NMR version 3.5 (Bruker, Karlsruhe, Germany). Two-dimensional $J$-resolved NMR spectra were acquired using 8 scans per 64 increments for $\mathrm{F} 1$ and $1,638.4 \mathrm{k}$ for $\mathrm{F} 2$ using spectral widths of $6,009.6 \mathrm{~Hz}$ in F2 (chemical shift axis) and $50 \mathrm{~Hz}$ in $\mathrm{F} 1$ (spin-spin coupling constant axis). A $1.5 \mathrm{~s}$ relaxation delay was employed. Datasets were zero filled to 512 points in $\mathrm{F} 1$ and both dimensions were multiplied by sine-bell functions $(\mathrm{SSB}=0)$. The $J$-resolved spectra were tilted by $45^{\circ}$, symmetrized about F1, and calibrated to TMSP- $d_{4}$ using XWIN NMR version 3.5 (Bruker, Karlsruhe, Germany). The correlation spectroscopy (COSY) spectra were acquired with a $1.0 \mathrm{~s}$ relaxation delay and $6,009.6 \mathrm{~Hz}$ spectral widths in both dimensions. The window function for the COSY spectra was sine-bell $(\mathrm{SSB}=0)$.

\section{Results and discussion}

\section{Root induction}

The adventitious roots were induced from leaves of G. procumbens by inoculating the explants on MS solid medium supplemented with different concentrations of IBA, NAA, or combinations of both PGRs. The initial adventitious roots formation was visible after 7 days of inoculation and the frequency of root induction was observed at several time points (Fig. 1). Significant differences of root induction frequency were noted dependent on PGR type, concentration, and time period. In single PGR treatment, rooting frequency increased at increasing NAA concentrations and was significantly higher in $5 \mathrm{mg} / \mathrm{l} \mathrm{NAA}$ as compared to $1 \mathrm{mg} / \mathrm{l} \mathrm{NAA}$ after 5 weeks of inoculation $(P<0.05)$. Furthermore, the rooting frequency increased consistently with the extension of incubation time. In contrast, when applying IBA, increasing concentrations of the PGR from 1 to $5 \mathrm{mg} / \mathrm{l}$ did not significantly enhance the root induction frequency $(P<0.05)$. Moreover, with IBA treatment, no increase in root induction was observed at prolonged time periods. This results show that NAA was favorable for inducing adventitious roots from leaf explants of G. procumbens. In another study, Praveen et al. (2009) also found that NAA is more potent in triggering induction of adventitious roots from leaf explants of Andrographis paniculata compared to IBA and IAA. In contrast, IBA was found effective than NAA to induce adventitious roots from leaf segments of Morinda citrifolia (Baque et al. 2010). This suggests that the response of root organogenesis to exogenous PGRs varies among plant species.

When leaf explants were inoculated on the MS medium supplemented with both NAA and IBA, the frequency of adventitious roots induction was increased at all time points. After 9 weeks of incubation, the medium with a combination of $3 \mathrm{mg} / \mathrm{l} \mathrm{NAA}+1 \mathrm{mg} / \mathrm{l}$ IBA gave the highest rooting frequency (48\%), even though the result is not statistical different from the treatments with $5 \mathrm{mg} / \mathrm{l}$ $\mathrm{NAA}$ and $3 \mathrm{mg} / \mathrm{l} \mathrm{IBA}+1 \mathrm{mg} / \mathrm{l} \mathrm{NAA}(P<0.05)$. Combining $3 \mathrm{mg} / \mathrm{l}$ IBA with $1 \mathrm{mg} / \mathrm{l}$ NAA significantly increased the root induction frequency up to $31 \%$ rather than only $6 \%$ in $3 \mathrm{mg} / \mathrm{l} \mathrm{IBA}$ after 9 weeks of incubation $(P<0.05)$. These results indicated that auxin-combined treatments could stimulate root induction frequency more than the individual auxin treatments, thus indicating a synergistic effect for inducing leaf explants-derived adventitious root cultures of $G$. procumbens. The result was in agreement with that described for different species in reports by Khosh-Khui and Sink (1982) and Pérez-Tornero et al. (2010).

In terms of root morphology, different characteristics were observed between IBA and NAA supplemented 


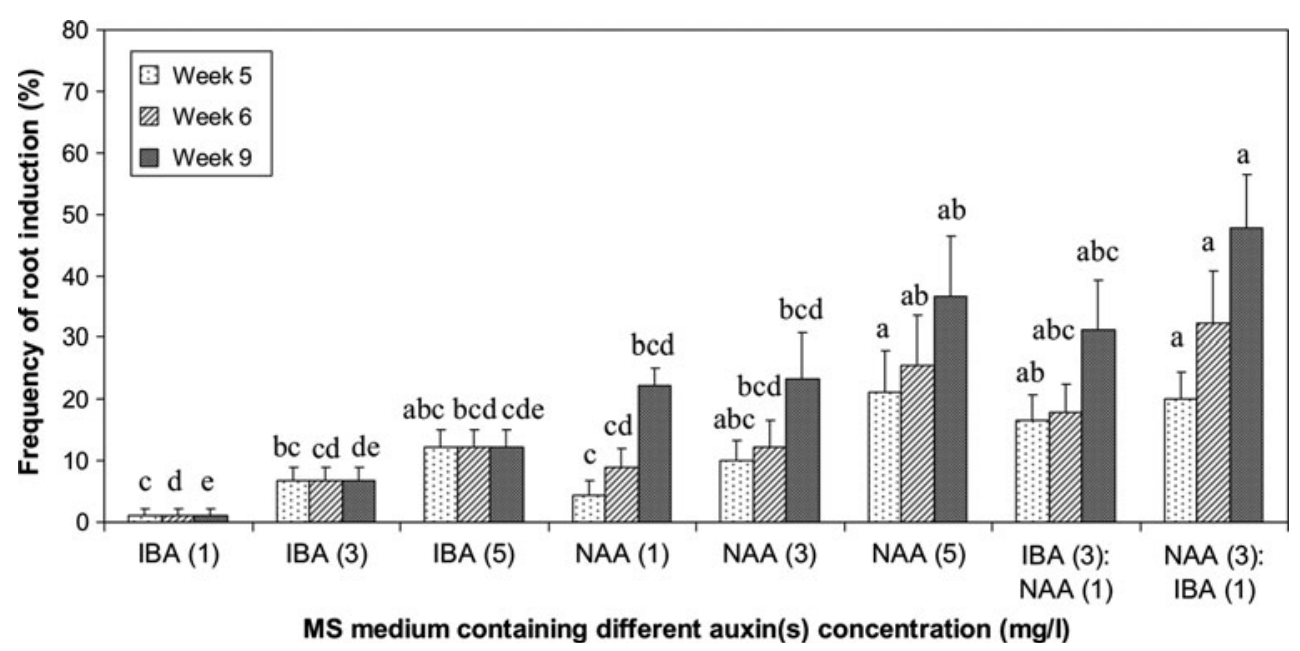

Fig. 1 Frequency of root induction from leaf explants of Gynura procumbens on MS medium supplemented with different concentrations of auxin(s). The number inside the brackets represents the concentration $(\mathrm{mg} / \mathrm{l})$ of the corresponding indole-3-butyric acid (IBA) or 1-naphthalene-acetic acid (NAA) in MS medium. Means consisting of 9 replicates petri dish with 10 explants in each petri dish. Means $\pm \mathrm{SE}$ with different letters of the same type of column are significantly different $(P<0.05)$ using DMRT media. On IBA-containing medium, the adventitious roots emerged directly from the cut edge of the leaf segments without callus induction phase and developed into fine, thin, and long roots which grew and branched inside the media (Fig. 2a). In contrast, on NAA-supplemented medium, the earlier protuberances originated from calli developing on leaf explants, which subsequently developed into thick, short, hairy, and multiple roots that grew upward, away from the media (Fig. 2b). The root morphology on the medium with a combination of NAA + IBA was like that of the roots formed on NAA medium regardless of higher or lower concentration of NAA and IBA in the medium (Fig. 2c).

Liquid culture and growth curve determination

In order to explore the potential for a large-scale culture system, the adventitious roots derived from leaf explants of G. procumbens were proliferated in liquid medium. For this purpose, the initial conditions delivering highest root induction frequency were selected for further investigation and optimization under liquid conditions. The adventitious roots induced on MS medium with a combination of $3 \mathrm{mg} / \mathrm{l}$ $\mathrm{NAA}+1 \mathrm{mg} / \mathrm{l}$ IBA were inoculated into the same liquid medium formulation. After 2 weeks in the liquid medium, the adventitious roots had proliferated and had produced more lateral roots (Fig. 2d, e).

The growth curve of the root cultures was determined based on the FW and DW accumulation over a period of 8 weeks (Fig. 3a, b). Regarding FW accumulation, the growth curve indicates a near linear pattern from beginning to the end of the time course. However, the growth curve for DW accumulation reveals a near linear increase for the first 6 weeks before reaching a growth plateau. At the end of the time course, the biomass was $4.70 \pm 0.46 \mathrm{~g} \mathrm{FW}$ and $0.50 \pm 0.03 \mathrm{~g} \mathrm{DW}$ which corresponds to a 2.3 -fold $(\mathrm{FW})$ and 3.2-fold (DW) increase compared to the initial inocula, respectively. Considering this result, the adventitious root cultures of $G$. procumbens have been shown amenable for growing in liquid culture.

A study on tissue culture conditions

Further optimization of culture parameters may deliver the key to a successful cultivation system and some of the culture conditions that may affect the root growth of G. procumbens have been investigated and described below.

\section{MS medium strength}

Medium strength may have significant effects on root growth or production of secondary metabolites in root cultures. Therefore, the effect of MS medium strength at half (1/2), normal (1), one and half (3/2), and double (2) strength was studied on the root culture of $G$. procumbens. The graph in Fig. 4a shows that the normal strength of MS medium produced the highest root FW $(13.9 \pm 0.43 \mathrm{~g})$ and root DW $(0.78 \pm 0.01 \mathrm{~g})$ after 4 weeks of inoculation. However, the result was not significantly different compared to other MS medium strengths $(P<0.05)$. In general, $1 / 2 \mathrm{MS}$ medium is usually employed to enhance roots induction and proliferation. For example, when the MS medium strength was reduced from 1 to $1 / 4$, rooting percentages of Syzygium alternifolium were increased and the 

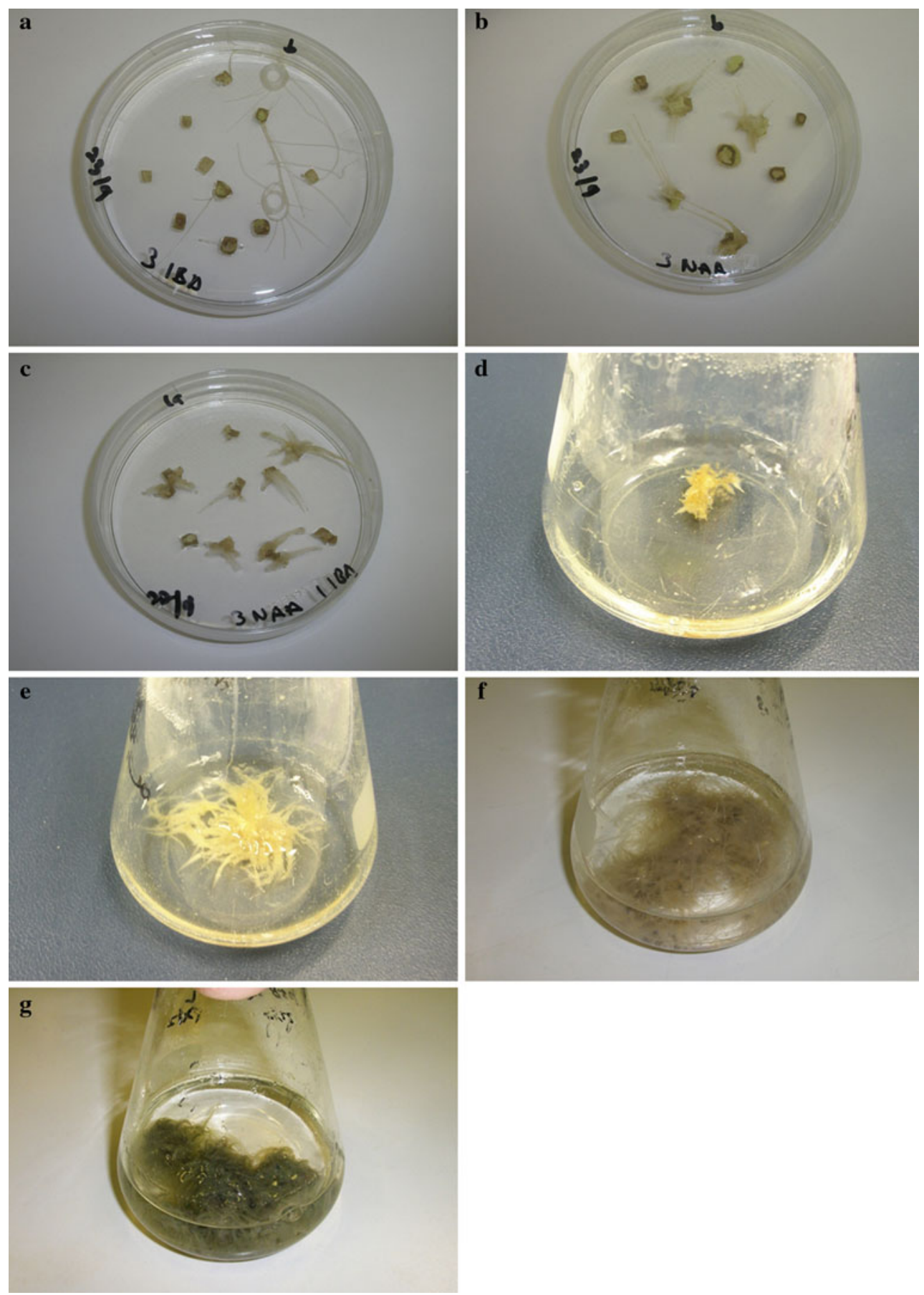

Fig. 2 The adventitious root culture induced from leaf explants of Gynura procumbens. Adventitious roots after 5 weeks cultured on MS medium supplemented with $3 \mathrm{mg} / \mathrm{l} \mathrm{IBA} \mathrm{(a);} 3 \mathrm{mg} / \mathrm{l} \mathrm{NAA} \mathrm{(b);} \mathrm{and}$ $3 \mathrm{mg} / \mathrm{l} \mathrm{NAA}+1 \mathrm{mg} / \mathrm{l} \mathrm{IBA}(\mathbf{c})$. Adventitious root culture initiated on

1/2MS medium was found more satisfactory for the root growth (Sha Valli Khan et al. 1999). Simões-Gurgel et al. (2011) found that the use of $1 / 2 \mathrm{MS}$ medium resulted in higher anthocyanin production in cell suspension culture of Cleome rosea when compared to cultures grown on $1 \mathrm{MS}$ or 1/4MS medium. In another study, medium replenishment

MS liquid medium containing $3 \mathrm{mg} / \mathrm{l} \mathrm{NAA}+1 \mathrm{mg} / \mathrm{l} \mathrm{IBA}$ at day 0 (d) and after 14 days (e). Adventitious root culture on MS liquid medium supplemented with $3 \mathrm{mg} / \mathrm{l} \mathrm{NAA}+1 \mathrm{mg} / \mathrm{l}$ IBA in dark (f) and under light condition (g)

strategy was implemented to increase biomass and metabolite production, e.g. the adventitious root growth of $P$. ginseng and the production of ginsenoside were significantly improved by changing the MS medium strength from $3 / 2 \mathrm{MS}$ to $1 \mathrm{MS}$ after 20 days of culture (Jeong et al. 2008). 
Fig. 3 The growth curve of Gynura procumbens root cultures in fresh weight (a) and dry weight (b). Values represent mean of two replicates flask $\pm \mathrm{SE}$

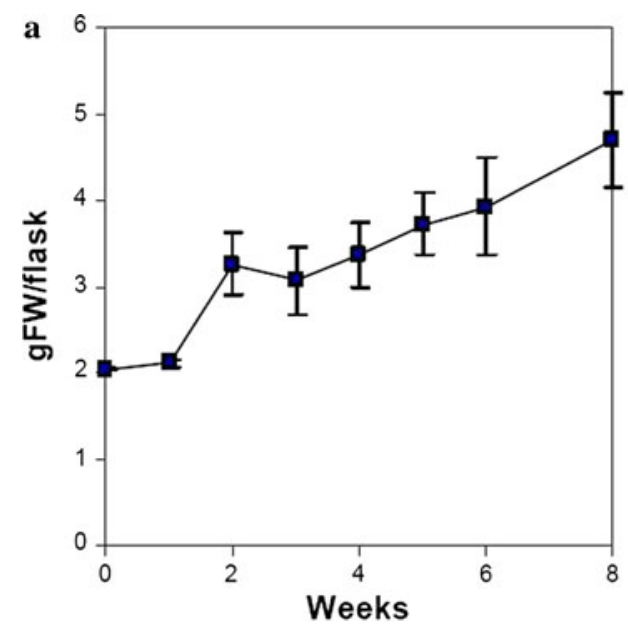

\section{Sucrose concentration}

In plant tissue culture, the external sugar such as sucrose is supplied into medium to serve as the primary source of energy for biosynthesis and tissue development. The effect of sucrose concentration from 1 to $10 \% \mathrm{w} / \mathrm{v}$ was studied to find the suitable sucrose level for the optimum growth of adventitious root cultures of $G$. procumbens. Figure $4 \mathrm{~b}$ shows that the root FW was significantly decreased with increasing sugar level in the medium $(P<0.05)$. In addition, it was observed that the root cultures in 7 and $10 \%$ w/v sucrose concentration media became tangled and turned brown after 4 weeks of inoculation. This result indicates that the roots were repressed when sucrose level was increased and this could be due to high osmotic pressure of the medium as noted in the study of $P$. ginseng (Kim et al. 2005) and Hypericum perforatum (Cui et al. 2010) adventitious root cultures, and cell suspension cultures of $C$. rosea (Simões-Gurgel et al. 2011). Although the root FW decreased in higher sucrose concentration level, the root DW depicted dissimilar pattern which show insignificant difference between 2 and $10 \% \mathrm{w} / \mathrm{v}$ sucrose concentrations $(P<0.05)$. This result could be attributed to the formation of extracellular polysaccharides correlated to the amount and consumption of sucrose in the medium. Overall, in this study, $2 \% \mathrm{w} / \mathrm{v}$ sucrose concentration gave the optimal result for the root cultures growth of G. procumbens as assessed from both FW (13.8 $\pm 1.60 \mathrm{~g})$ and DW $(0.69 \pm 0.07 \mathrm{~g})$ of biomass after 4 week of incubation.

On the other hand, Kim et al. (2005) found that $3 \% \mathrm{w} / \mathrm{v}$ was the most favorable initial sucrose concentration for the adventitious root growth and saponin content of $P$. ginseng. Cui et al. (2010) also found that $3 \% \mathrm{w} / \mathrm{v}$ sucrose was optimal for the adventitious roots growth of $H$. perforatum, whereas the secondary metabolites level was favoured at higher sucrose concentration $(5-9 \% \mathrm{w} / \mathrm{v})$ due to the osmotic stress.
Instead of using the initial sucrose concentration, Hao and Guan (2012) showed that controlling sucrose concentration by multiple addition of fresh sucrose at different time points can enhance the adventitious roots proliferation and saikosaponin production of Bupleurum chinense.

\section{Initial medium $\mathrm{pH}$}

The effect of initial medium $\mathrm{pH}$ on root cultures of $G$. procumbens was investigated at different $\mathrm{pH}$ values ranging from 5.0 to 6.5 (Fig. 4c). The highest root FW $(12.0 \pm 1.46 \mathrm{~g})$ was acquired at the initial medium $\mathrm{pH}$ of 5.5 which is statistically significant when compared to the higher initial medium $\mathrm{pH}$ of $6.0-6.5(P<0.05)$. Although the DW growth pattern at different medium $\mathrm{pH}$ was found similar to the root FW values, the DW biomasses were not significantly different for the different $\mathrm{pH}$ values $(P<0.05)$. Based on this result, $\mathrm{pH} 5.5$ demonstrated as the best initial medium $\mathrm{pH}$ for the optimal growth of $G$. procumbens root cultures. On the other hand, Ho and Shanks (1992) found that the initial medium $\mathrm{pH}$ of 6.5 gave the maximum growth rate for Catharanthus roseus hairy root cultures, while the lowest growth rate was acquired at pH 4.2 and 7.3. Kim et al. (2005) showed that the initial medium $\mathrm{pH}$ did not significantly affect the adventitious roots growth of $P$. ginseng but apparently influenced the saponin content.

\section{Light versus dark}

In general, root cultures are cultivated in the dark as its natural environment. However, light may have a pronounced effect on growth and phenotype of root cultures, which can vary between plant species. Taya et al. (1994) showed that Ipomoea aquatica hairy roots produced higher biomass in the light as compared to the dark. Conversely, Mukundan and Hjorts $\varnothing$ (1991) reported that light inhibited 

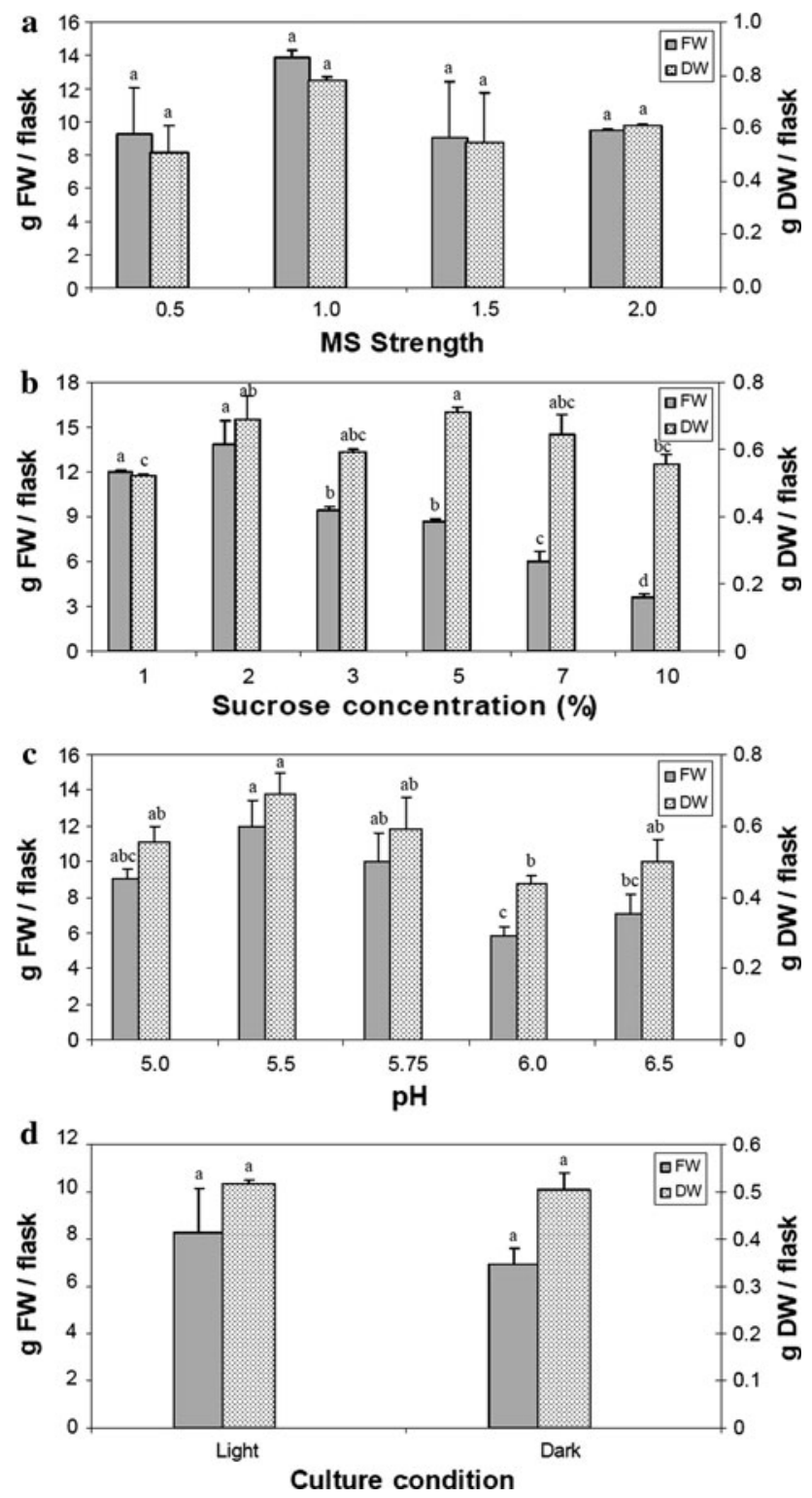

Fig. 4 Fresh weight (FW) and dry weight (DW) of the root culture of Gynura procumbens in different MS medium strength (a), sucrose concentration (b), initial medium $\mathrm{pH}(\mathbf{c})$, and light or dark condition (d). Means are derived from three replicates in $\mathbf{a}-\mathbf{c}$, and five replicates in d. Means $\pm \mathrm{SE}$ with different letters of the same type of column are significantly different $(P<0.05)$ using DMRT

the hairy root growth of Tagetes patula. In order to study the effect of light versus dark, the root cultures of $G$. procumbens were placed under continuous fluorescent light (1,500-2,000 lux) or in dark. As a result, no significant differences were observed with the root cultures of $G$. procumbens neither in the FW nor DW of biomass after 4 weeks of incubation (Fig. 4d). Although the root biomass was not affected, the root color was different as the roots exposed to the light had turned green (Fig. 2f, g). This result was similar to those found in the hairy root culture of

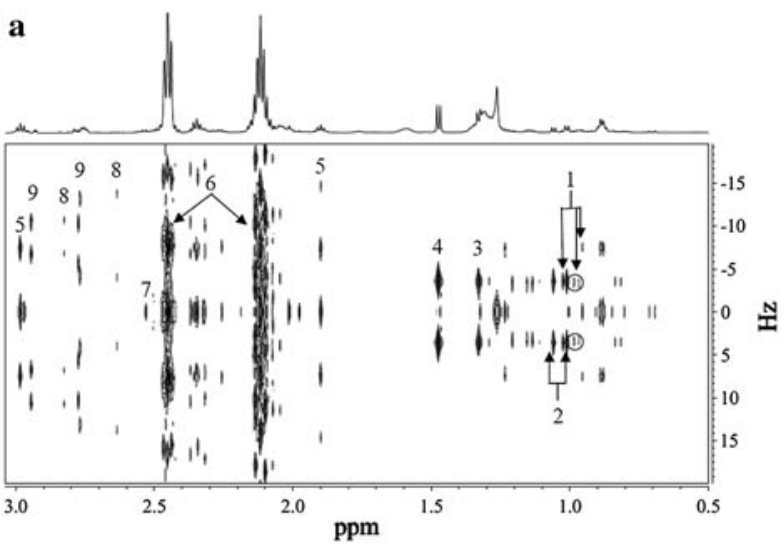

b

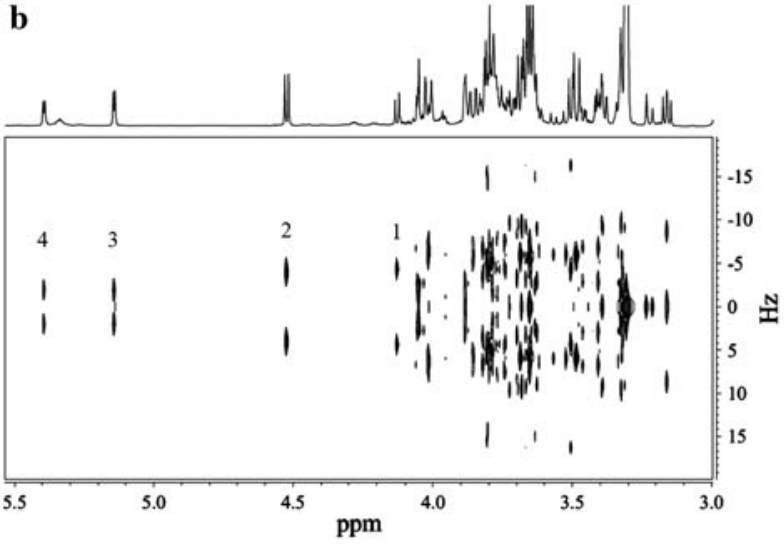

c

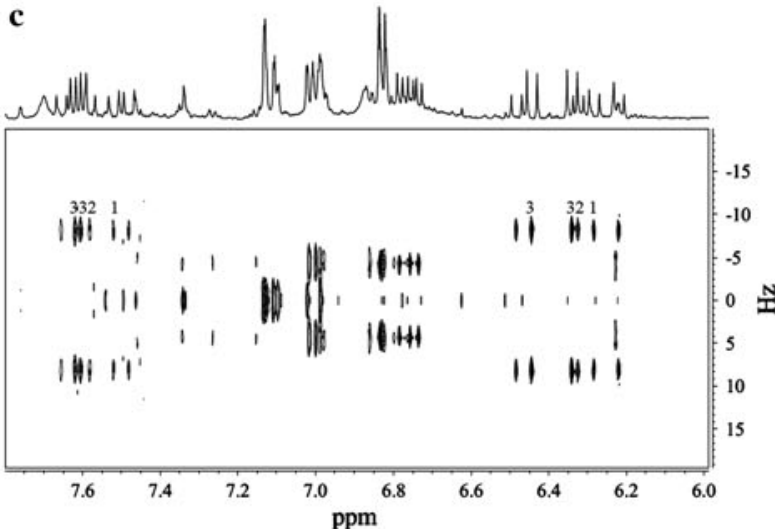

d

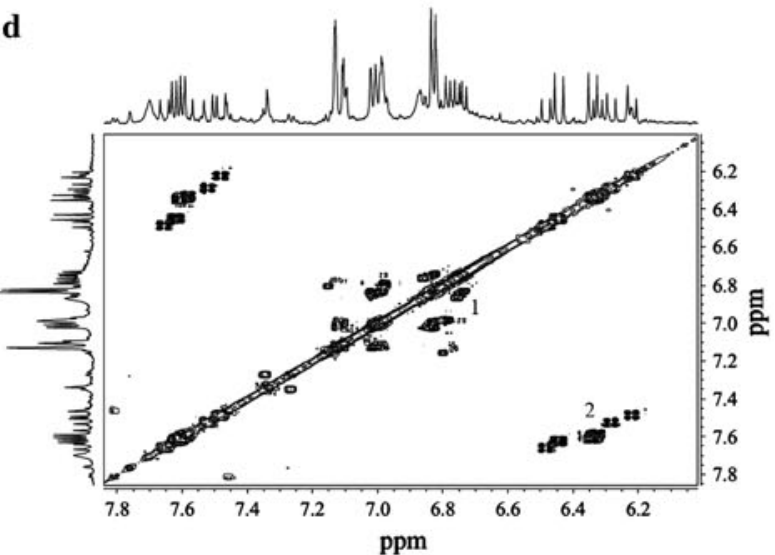


4Fig. 5 Two-dimensional $J$-resolved NMR spectra of the adventitious root culture of Gynura procumbens in the range of $\delta 0.5-\delta 3.0$ (a), $\delta$ $3.0-\delta 5.5$ (b), $\delta 6.0-\delta 7.8$ (c) and correlation spectroscopy (COSY) in the range of $\delta 6.0-\delta 7.8$ (d). J-resolved a shows 1 leucine and isoleucine, 2 valine, 3 threonine, 4 alanine, $5 \gamma$-aminobutyric acid (GABA), 6 glutamic acid, 7 succinic acid, 8 malic acid, 9 aspartic acid. $J$-resolved $\mathbf{b}$ shows 1 fructose moiety of sucrose, $2 \beta$-glucose, 3 $\alpha$-glucose, 4 glucose moeity of sucrose. $J$-resolved c shows 1 caffeic acid, 2 chlorogenic acid, 3 3,5-di- $O$-caffeoylquinic acid. COSY d shows correlation between $1 \mathrm{H}-5$ and $\mathrm{H}-6,2 \mathrm{H}-7$ and $\mathrm{H}-8$ of phenylpropanoids

Amsonia elliptica, Lippia dulcis, and Digitalis lanata when incubated in the light. In those examples, further studies revealed that $D$. lanata hairy roots contained chloroplasts, A. elliptica hairy roots had unique amyloplast-like structures, and the intermediate structures were found in $L$. dulcis hairy roots (Toda et al. 2002). This study concluded that light or dark conditions did not affect the root biomass of $G$. procumbens but the roots developed chloroplast-like structures under light condition.

Metabolite analysis

The 4-week-old adventitious roots of $G$. procumbens cultured in the liquid medium were analyzed with
${ }^{1} \mathrm{H}-\mathrm{NMR}$ and 2D-NMR ( $J$-resolved and COSY) to characterize its metabolite content. The assignments of NMR signals were made based on the previous reports (Choi et al. 2006; Leiss et al. 2009) and the database of metabolites spectra from the Natural Products Laboratory, Leiden University, The Netherlands. In principal, a ${ }^{1} \mathrm{H}-$ NMR spectrum is divided into three regions, i.e. amino acid and organic acid region $(\delta 0.8-\delta 4.0)$, sugar region $(\delta$ $4.1-\delta 5.5)$, and aromatic region $(\delta 5.6-\delta 8.5)$. In the amino acid or organic acid region (Fig. 5a), the adventitious root sample of G. procumbens showed signals of leucine and isoleucine, valine, threonine, alanine, $\gamma$-aminobutyric acid (GABA), glutamic acid, succinic acid, aspartic acid, and malic acid. In the sugar region, the signals of anomeric protons of $\beta$-glucose, $\alpha$-glucose, and sucrose were detected (Fig. 5b). The characteristic singlet at $\delta 8.46$ was identified as formic acid. In the aromatic region, at least 6 signals of phenylpropanoids were observed (Fig. 5c). It is well known that the doublet signal with a coupling constant of $J=16.0 \mathrm{~Hz}$ between $\delta 6.20-\delta 6.50$ represents the H-8 proton of phenylpropanoids (Choi et al. 2006). The six major doublets of H-8 proton of phenylpropanoids were confirmed by a correlation with the $\mathrm{H}-7$ proton in the region of $\delta 7.45-\delta 7.65$ in the COSY spectrum (Fig. 5d). Some of these signals are assigned to olefinic protons of
Table 1 The chemical shift $(\delta$ in ppm) and coupling constants $(J$ in $\mathrm{Hz})$ of some metabolites detected in ${ }^{1} \mathrm{H}$-NMR and $J$ resolved spectra of adventitious root of Gynura procumbens

$s$ singlet, $d$ doublet, $d d$ double doublet, $d d d$ doublet of double of doublet, $t$ triplet, $q$ quartet, $m$ multiplet

\begin{tabular}{ll}
\hline Compounds & Chemical shift $(\mathrm{ppm})$ and coupling constant $(\mathrm{Hz})$ \\
\hline Leucine and isoleucine & $\delta 0.97(\mathrm{~d}, J=6.5) ; \delta 0.95(\mathrm{t}, J=7.5) ; \delta 0.99(\mathrm{~d}, J=6.5) ;$ \\
& $\delta 1.03(\mathrm{~d}, J=7.0)$ \\
Valine & $\delta 1.01(\mathrm{~d}, J=7.0, \mathrm{H}-4) ; \delta 1.05(\mathrm{~d}, J=7.0, \mathrm{H}-5) ; \delta 2.39(\mathrm{~m}, \mathrm{H}-3)$ \\
Threonine & $\delta 1.33(\mathrm{~d}, J=6.8, \mathrm{H}-4)$ \\
Alanine & $\delta 1.48(\mathrm{~d}, J=7.0, \mathrm{H}-3)$ \\
$\gamma$-Aminobutyric acid $(\mathrm{GABA})$ & $\delta 1.90(\mathrm{q}, J=7.5) ; \delta 2.35(\mathrm{t}, J=7.5) ; \delta 2.98(\mathrm{t}, J=8.0)$ \\
Glutamic acid & $\delta 2.12(\mathrm{~m}, \mathrm{H}-\beta) ; \delta 2.46(\mathrm{~m}, \mathrm{H}-\gamma)$ \\
Succinic acid & $\delta 2.53(\mathrm{~s})$ \\
Malic acid & $\delta 2.83(\mathrm{dd}, J=17.0,3.5) ; \delta 2.63(\mathrm{dd}, J=17.0,9.0)$ \\
Aspartic acid & $\delta 2.77(\mathrm{dd}, J=17.0,9.0) ; \delta 2.95(\mathrm{dd}, J=17.0,4.0)$ \\
Fructose moiety of sucrose & $\delta 4.13(\mathrm{~d}, J=8.6)$ \\
$\beta$-Glucose & $\delta 4.52(\mathrm{~d}, J=8.0, \mathrm{H}-1)$ \\
$\alpha$-Glucose & $\delta 5.14(\mathrm{~d}, J=4.0, \mathrm{H}-1)$ \\
Glucose moiety of sucrose & $\delta 5.40(\mathrm{~d}, J=4.0)$ \\
Formic acid & $\delta 8.46(\mathrm{~s})$ \\
Caffeic acid & $\delta 6.28(\mathrm{~d}, J=16.0, \mathrm{H}-8) ; \delta 6.83(\mathrm{~d}, J=8.0, \mathrm{H}-5) ;$ \\
& $\delta 7.00(\mathrm{dd}, J=8.0,2.0, \mathrm{H}-6) ; \delta 7.11(\mathrm{~d}, J=2.0, \mathrm{H}-2) ;$ \\
& $\delta 7.52(\mathrm{~d}, J=16.0, \mathrm{H}-7)$ \\
Chlorogenic acid & $\delta 6.32\left(\mathrm{~d}, J=16.0, \mathrm{H}-8^{\prime}\right) ; \delta 6.83\left(\mathrm{~d}, J=8.0, \mathrm{H}-5^{\prime}\right) ; \delta 7.02(\mathrm{dd}, J=8.0$, \\
& $\left.2.0, \mathrm{H}-6^{\prime}\right) ; \delta 7.13\left(\mathrm{~d}, J=2.0, \mathrm{H}-2^{\prime}\right) ; \delta 7.58\left(\mathrm{~d}, J=16.0, \mathrm{H}-7^{\prime}\right) ; \delta 5.34$ \\
& $(\mathrm{ddd}, J=11.0,10.0,5.0, \mathrm{H}-5)$ \\
3,5 -di- $O$-caffeoylquinic acid & $\delta 6.44\left(\mathrm{~d}, J=16.0, \mathrm{H}-8^{\prime}\right) ; 6.83\left(\mathrm{~d}, J=8.0, \mathrm{H}-5^{\prime}\right) ; \delta 7.02(\mathrm{dd}, J=8.0$, \\
& $\left.2.0, \mathrm{H}-6^{\prime}\right) ; \delta 7.13\left(\mathrm{~d}, J=2.0, \mathrm{H}-2^{\prime}\right) ; \delta 7.62\left(\mathrm{~d}, J=16.0, \mathrm{H}-7^{\prime}\right) ; \delta 6.34$ \\
& $\left(\mathrm{~d}, J=16.0, \mathrm{H}-8^{\prime \prime}\right) ; \delta 6.83\left(\mathrm{~d}, J=8.0, \mathrm{H}-5^{\prime \prime}\right) ; \delta 7.00(\mathrm{dd}, J=8.0,2.0$, \\
& $\left.\mathrm{H}-6^{\prime \prime}\right) ; \delta 7.11\left(\mathrm{~d}, J=2.0, \mathrm{H}-2^{\prime \prime}\right) ; \delta 7.61\left(\mathrm{~d}, J=16.0, \mathrm{H}-7^{\prime \prime}\right) ; \delta 5.49$ \\
& $(\mathrm{ddd}, J=11.8,10.0,5.0, \mathrm{H}-5)$ \\
\hline & \\
\hline & \\
&
\end{tabular}


caffeic acid, cholorogenic acid, and 3,5-di- $O$-caffeoylquinic acid. The H-8 resonances of those phenylpropanoids are correlated to $\mathrm{H}-7$ signals. The resonance at $\delta 6.28(\mathrm{~d}$, $J=16.0 \mathrm{~Hz}, \mathrm{H}-8)$ correlate to $\delta 7.52(\mathrm{~d}, J=16.0 \mathrm{~Hz}$, H-7) for caffeic acid, at $\delta 6.32\left(\mathrm{~d}, J=16.0 \mathrm{~Hz}, \mathrm{H}-8^{\prime}\right)$ to $\delta$ $7.58\left(\mathrm{~d}, J=16.0 \mathrm{~Hz}, \mathrm{H}-7^{\prime}\right)$ for chlorogenic acid, at $\delta 6.44$ $\left(\mathrm{d}, J=16.0 \mathrm{~Hz}, \mathrm{H}-8^{\prime}\right)$ to $\delta 7.62\left(\mathrm{~d}, J=16.0 \mathrm{~Hz}, \mathrm{H}-7^{\prime}\right)$ and at $\delta 6.34\left(\mathrm{~d}, J=16.0 \mathrm{~Hz}, \mathrm{H}-8^{\prime \prime}\right)$ to $\delta 7.61(\mathrm{~d}$, $\left.J=16.0 \mathrm{~Hz}, \mathrm{H}-7^{\prime \prime}\right)$ for 3,5-di- $O$-caffeoylquinic acid. The $\mathrm{H}-5$ signal of the quinic acid moiety is detected at $\delta 5.34$ (ddd, $J=11.0,10.0,5.0 \mathrm{~Hz}$ ) for chlorogenic acid and $\delta$ 5.49 (ddd, $J=11.8,10.0,5.0 \mathrm{~Hz}$ ) for 3,5-di- $O$-caffeoylquinic acid. The chemical shifts of ${ }^{1} \mathrm{H}-\mathrm{NMR}$ and coupling constants of $J$-resolved of the identified compounds are summarized in Table 1.

The root cultures of $G$. procumbens induced from the leaf explants showed signals of phenylpropanoids which were identified as caffeic acid, chlorogenic acid, and 3,5di- $O$-caffeoylquinic acid using NMR spectroscopy. These compounds are analogues of hydroxycinnamic acid which function as intermediate in the biosynthesis of lignin, a component of cell wall and biomass. Besides their physiological function in plants, these compounds also have therapeutic potential for human. Caffeic acid and chlorogenic acid have anti-oxidant and anti-cancer activities (review in Korkina 2007), while 3,5-di- $O$ caffeoylquinic acid exhibited anti-viral activity (Jiratchariyakul et al. 2000). However, the bioactive flavonol-glucosides that were found in the leaves of G. procumbens and associated to anti-diabetic activity (Akowuah et al. 2002) were not detected in the root culture. Interestingly, no signals of pyrrolizidine alkaloids which are associated with Gynura species were detected thus suggesting that the compounds were not present or produced at too low levels to be detectable in the adventitious root culture. Therefore, the adventitious root culture of G. procumbens can be an interesting alternative source for the production of desired metabolites and devoid of unwanted, toxic compounds.

In this study, the metabolite content of adventitious root cultures initiated from leaf explants of G. procumbens has been characterized for the first time by using NMR spectroscopy. NMR is a powerful tool for identifying compounds present in biological samples. As compared to other analytical methods, NMR gives highly reproducible data, allows simultaneous analysis of a broad spectrum of metabolites, simple extraction method, fast measuring time, and easy quantitation without the need of a calibration curve for each single compound (Kim et al. 2010). Therefore, it gives an advantage for analyzing a wide range of metabolites without prior knowledge of the compounds in particular plant or cell cultures.

\section{Conclusion}

In conclusion, plant cell and organ culture are a promising approach to obtain plant specific bioactive compounds. An alternative culture system producing valuable phytochemicals has been successfully developed by inducing adventitious root culture from leaf explants of $G$. procumbens. The simple culture technique, easy cultivation, and rapid root proliferation make the root culture feasible for a large-scale production system. The adventitious root culture of $G$. procumbens is of interest to be further explored as the source of phenylpropanoids that might have interesting pharmacological activities connected with the traditional use of this plant.

Acknowledgments The authors thank Ministry of Higher Education of Malaysia and University of Malaya, Malaysia for the financial support of Mohd Zuwairi Saiman.

Open Access This article is distributed under the terms of the Creative Commons Attribution Noncommercial License which permits any noncommercial use, distribution, and reproduction in any medium, provided the original author(s) and source are credited.

\section{References}

Akowuah GA, Sadikun A, Mariam A (2002) Flavonoid identification and hypoglycaemic studies of the butanol fraction from Gynura procumbens. Pharm Biol 40(6):405-410

Baque MA, Hahn EJ, Paek KY (2010) Induction mechanism of adventitious root from leaf explants of Morinda citrifolia as affected by auxin and light quality. In Vitro Cell Dev Biol Plant 46:71-80

Choi YH, Kim HK, Linthorst HJM, Hollander JG, Lefeber AWM, Erkelens C, Nuzillard JM, Verpoorte R (2006) NMR metabolomics to revisit the tobacco mosaic virus infection in Nicotiana tabacum leaves. J Nat Prod 69:742-748

Cui XH, Murthy HN, Wu CH, Paek KY (2010) Sucrose-induced osmotic stress affects biomass, metabolite, and antioxidant levels in root suspension cultures of Hypericum perforatum L. Plant Cell Tiss Organ Cult 103:7-14

Cui L, Wang ZY, Zhou XH (2011) Optimization of elicitors and precursors to enhance valtrate production in adventitious roots of Valeriana amurensis Smir. ex Kom. Plant Cell Tiss Organ Cult (in press). doi:10.1007/s11240-011-0052-2

Dai N, Yu YC, Ren TH, Wu JG, Jiang Y, Shen LG, Zhang J (2007) Gynura root induces hepatic veno-occlusive disease: a case report and review of the literature. World $\mathrm{J}$ Gastroenterol 13(10):1628-1631

Hao JP, Guan Q (2012) Synthesis of saikosaponins in adventitious roots of Bupleurum chinense by semi-continuous culture. Plant Cell Tiss Organ Cult 108:159-165

Hassan Z, Yam MF, Ahmad M, Yusof APM (2010) Antidiabetic properties and mechanism of action of Gynura procumbens water extract in streptozotocin-induced diabetic rats. Molecules 15:9008-9023

Ho CH, Shanks JV (1992) Effects of initial medium pH on growth and metabolism of Catharanthus roseus hairy root cultures - a study with ${ }^{31} \mathrm{P}$ and ${ }^{13} \mathrm{C}$ NMR spectroscopy. Biotechnol Lett 14:959-964 
Hoe SZ, Kamaruddin MY, Lam SK (2007) Inhibition of angiotensinconverting enzyme activity by a partially purified fraction of Gynura procumbens in spontaneously hypertensive rats. Med Princ Pract 16:203-208

Iskander MN, Song Y, Coupar IM, Jiratchariyakul W (2002) Antiinflammatory screening of the medicinal plant Gynura procumbens. Plant Food Hum Nutr 57:233-244

Jeong CS, Murthy HN, Hahn EJ, Paek KY (2008) Improved production of ginsenosides in suspension cultures of ginseng by medium replenishment strategy. J Biosci Bioeng 105:288-291

Jiratchariyakul W, Jarikasem S, Siritantikorn S, Somanabandhu A, Frahm AW (2000) Antiherpes simplex viral compounds from Gynura procumbens Merr. Mahidol Univ Annu Res Abstr 28:182

Keng CL, Yee LS, Pin PL (2009) Micropropagation of Gynura procumbens (Lour.) Merr. An important medicinal plant. J Med Plant Res 3(3):105-111

Khosh-Khui M, Sink KC (1982) Rooting-enhancement of Rosa hybrida for tissue culture propagation. Sci Hort 17:371-376

Kim JH, Chang EJ, Oh HI (2005) Saponin production in submerged adventitious root culture of Panax ginseng as affected by culture condition and elicitors. Asia Pacific J Mol Biol Biotechnol 13:87-91

Kim HK, Choi YH, Verpoorte R (2010) NMR-based metabolomic analysis of plants. Nat Protoc 5:536-549

Kim HK, Choi YH, Verpoorte R (2011) NMR-based plant metabolomics: where do we stand, where do we go? Trends Biotechnol 29(6):267-275

Kim SW, Kim JH, Ahn MS, Choung DH, Liu JR (2011) Metabolic evaluation of cellular differentiation of tobacco leaf explants in response to plant growth regulators in tissue cultures using ${ }^{1} \mathrm{H}$ NMR spectroscopy and multivariate analysis. Plant Cell Tiss Organ Cult (in press). doi:10.1007/s11240-011-0044-2

Korkina LG (2007) Phenylpropanoids as naturally occurring antioxidants: from plant defense to human health. Cell Mol Biol $53: 15-25$

Leiss KA, Maltese F, Choi YH, Verpoorte R, Klinkhamer PGL (2009) Identification of chlorogenic acid as a resistance factor for thrips in Chrysanthemum. Plant Physiol 150:1567-1575

Mukundan U, Hjorts $\varnothing$ M (1991) Effect of light on growth and thiophene accumulation in transformed roots of Tagetes patula. J Plant Physiol 138:252-255

Murashige T, Skoog F (1962) A revised medium for rapid growth and bioassays with tobacco tissue cultures. Physiol Plant 15:473-497
Paek KY, Chakrabarty D, Hahn EJ (2005) Application of bioreactor systems for large scale production of horticultural and medicinal plants. Plant Cell Tiss Organ Cult 81:287-300

Pérez-Tornero O, Tallón CI, Porras I (2010) An efficient protocol for micropropagation of lemon (Citrus limon) from mature nodal segments. Plant Cell Tiss Organ Cult 100:263-271

Perry LM, Metzger J (1980) Medicinal Plants of East and South East Asia: attributed properties and uses. The MIT Press, Cambridge

Praveen N, Manohar SH, Naik PM, Nayeem A, Jeong JH, Murthy HN (2009) Production of andrographolide from adventitious root cultures of Andrographis paniculata. Curr Sci 96:694-697

Qi X, Wu B, Cheng Y, Qu H (2009) Simultaneous characterization of pyrrolizidine alkaloids and $\mathrm{N}$-oxides in Gynura segetum by liquid chromatography/ion trap mass spectrometry. Rapid Commun Mass Spectrom 23:291-302

Reis RV, Borges APPL, Chierrito TPC et al (2011) Establishment of adventitious root culture of Stevia rebaudiana Bertoni in a roller bottle system. Plant Cell Tissue Organ Cult 106:329-335

Rosidah, Yam MF, Sadikun A, Ahmad M, Akowuah GA, Asmawi MZ (2009) Toxicology evaluation of standardized methanol extract of Gynura procumbens. J Ethnopharmacol 123:244-249

Sha Valli Khan PS, Hausman JF, Rao KR (1999) Effect of agar, MS medium strength, sucrose and polyamines on in vitro rooting of Syzgium alternifolium. Biol Plant 42:333-340

Simões-Gurgel C, Cordeiro LDS, de Castro TC, Callado $\mathrm{CH}$, Albarello N, Mansur E (2011) Establishment of anthocyaninproducing cell suspension cultures of Cleome rosea Vahl ex DC. (Capparaceae). Plant Cell Tissue Organ Cult 106:537-545

Taya M, Sato H, Masahiro K, Tone S (1994) Characterization of pakbung green hairy roots cultivated under light irradiation. J Ferment Bioeng 78:42-48

Toda Y, Aoki T, Yoshimatsu K, Shimomura K (2002) Photosynthetic activity in green hairy roots: ultrastructure of plastid and correlation of chlorophyll and secondary metabolites. Nat Med $56: 173-177$

Wu CH, Murthy HN, Hahn EJ, Paek KY (2007) Large-scale cultivation of adventitious root of Echinacea purpurea in airlift bioreactors for the production of chichoric acid, chlorogenic acid and caftaric acid. Biotechnol Lett 29:1179-1182

Zhang XF, Tan BK (2000) Effects of an ethanolic extract of Gynura procumbens on serum glucose, cholesterol and triglyceride levels in normal and streptozotocin-induced diabetic rats. Singapore Med J 41(1):9-13 